\title{
PROBIOTIK UNTUK KEHAMILAN : A REVIEW
}

\author{
Rina Tri Handayani ${ }^{1, *}$, Ferry Mustofa ${ }^{2}$, Citra Puspita ${ }^{3}$, Rejo $^{4}$, Joko Tri \\ Atmojo 5 \\ 1,2,3,4,5 STIKES Mamba'ul 'Ulum Surakarta \\ 1trihandayanirina@gmail.com*
}

\begin{abstract}
Abstrak
Latar Belakang: Kesehatan sistem pencernaan selama kehamilan mengambil peranan penting dalam proses metabolisme, pemrograman imunologis janin dan menyuplai nutrisi bagi ibu dan janin. Atas dasar ini, mikrobiota usus ibu dianggap berkontribusi terhadap terhadap kesehatan ibu dan janin. Penggunaan probiotik adalah salah satu metode yang dapat digunakan untuk memelihara kesehatan usus, mengaktivitasi mikrobiota agar dapat bermanfaat untuk imunitas, mencegah gangguan atopik, bakterial vaginosis, diabetes mellitus gestasional (GDM) dan hipertensi pada kehamilan.

Tujuan: Mengulas manfaat probiotik untuk kehamilan dan kesehatan wanita.

Metode: Review ini dilakukan penulis dengan menelusuri database diantaranya PubMed, Google scholar, dan open access science direct untuk mengetahui potensi studi yang memenuhi syarat. Kata kunci yang digunakan antara lain: 'Probiotic for pregnancy 'ATAU' 'Probiotic AND hypertension AND Prenancy' ATAU Probiotic AND Diabetus mellitus" ATAU 'Probiotic AND Pregnancy AND Review'. Penelusuran ini dilakukan mulai dari Februari hingga Maret 2020

Hasil: Bakteri jenis Lactobacillus dan Bifidobacterium dapat mengobati dan mencegah bakterial vainosis dengan memproduksi zat antibakteri antara lain reutericyclin, asam organik, bakteriosin, reuterin dan hidrogen peroksida. Hidrogen peroksida (H2O2). Bakteri jenis Streptococcus, Escherichia, Lactobacillus, dan Bifidobacterium dapat mensintesis neurotransmiter dalam sistem saraf otonom, mengubah tonus pembuluh darah, mengubah fungsi endotel, dan memproduksi asam lemak / Short Chain Fatty Acid (SCFA) untuk menurunkan tekanan darah. Selain itu Lactobacillus rhamnosus GG dan Bifidobacterium lactis BB12 dilaporkan dapat menurunkan kdar insulin dan risiko GDM
\end{abstract}

Simpulan: Probiotik merupakan mikroba normal yang ada di dalam tubuh, sehingga penambahan dan penggunaannya dalam terapi dapat dipertimbangkan. Belum dilaporkan adanya efek samping berarti dari penggunaan probiotik dalam jangka panjang ataupun pendek, sehingga alternatif terapi probiotik sangat diperhitungkan untuk diberikan pada ibu hamil.

Kata Kunci: Probiotic; Kehamilan; Review

\section{PROBIOTIK FOR PREGNANCY : A REVIEW}

Abstract
Background: The health of the digestive system during pregnancy takes an
important role in the process of metabolism, immunological programming of the 
fetus and supplying nutrients for the mother and fetus. On this basis, maternal intestinal microbiota is thought to contribute to the health of the mother and fetus. The use of probiotics is one method that can be used to maintain intestinal health, activate microbiota to be beneficial for immunity, prevent atopic disorders, bacterial vaginosis, gestational diabetes mellitus (GDM) and hypertension in pregnancy.

The Purpose: To review the benefits of probiotics for pregnancy and women's health.

Method: This review was conducted by the author by searching databases including PubMed, Google scholar, and open access science direct to find out the potential of eligible studies. Keywords used include: 'Probiotic for pregnancy' OR " Probiotic AND hypertension AND Prenancy 'OR Probiotic AND Diabetus mellitus "OR" Probiotic AND Pregnancy AND Review". This search was conducted from February to March 2020

Results: Lactobacillus and Bifidobacterium can treat and prevent bacterial vainosis by producing antibacterial agents such as reutericyclin, organic acids, bacteriocin, reuterin and hydrogen peroxide. Hydrogen peroxide (H2O2). Streptococcus, Escherichia, Lactobacillus, and Bifidobacterium can synthesize neurotransmitters in the autonomic nervous system, change blood vessel tone, change endothelial function, and produce fatty acids / Short Chain Fatty Acid (SCFA) to reduce blood pressure. In addition, Lactobacillus rhamnosus GG and Bifidobacterium lactis BB12 have been reported to reduce insulin levels and the risk of GDM

Conclusion: Probiotics are normal microbes in the body, so the addition and use in therapy can be considered. No significant side effects have been reported from the use of probiotics in the long or short term, so probiotic can be an alternative therapy to be given to pregnant women.

Keywords: Probiotic; Pregnancy; Review

\section{PENDAHULUAN}

Kehamilan adalah masa perkembangan yang kritis bagi janin, kondisi kesehatan ibu, rangsangan tertentu dan status gizi ibu dapat 'memprogram' fungsi dan kesehatan jangka panjang dari janin yang dikandung (Lindsay et al., 2013).

Sistem pencernaan ibu mengambil peranan penting dalam memproses metabolisme, pemrograman imunologis janin dan menyuplai nutrisi bagi ibu dan janin. Atas dasar ini, mikrobiota usus ibu dianggap berkontribusi terhadap terhadap kesehatan ibu dan janin (Cani and Delzenne, 2007).

Penggunaan probiotik adalah salah satu metode yang dapat digunakan untuk memelihara kesehatan usus, mengaktivitasi mikrobiota agar dapat dimanipulasi untuk mendapatkan manfaat kesehatan (Tilg and Kaser, 2011). Penggunaan probiotik pada kehamilan juga telah diteliti dapat bermanfaat untuk imunitas, mencegah gangguan atopik, bakterial vaginosis, diabetes mellitus gestasional (GDM) dan hipertensi (Lindsay et al., 2013; Gomez-Arango et al., 2016).

Pada kehamilan, mikrobiota usus berubah dengan perkembangan kehamilan. Pada trimester kedua, kelimpahan genus bakteri kelimpahan Collinsella 
berkorelasi positif level insulin, sedangkan kelimpahan Odoribacter berkorelasi negatif dengan tekanan darah. Pada trimester ketiga kehamilan, keragaman intraindividu, namun kelimpahan proteobacteria filum pro-inflamasi (Pelzer et al., 2017).

Penelitian sebelumnya telah banyak mengulas manfaat probiotik untuk kehamilan dan kesehatan wanita, sehingga peneliti tertarik untuk membuat review mengenai berbagai manfaat probiotik bagi kesehatan ibu hamil.

\section{METODE}

Review ini dilakukan penulis dengan menelusuri database diantaranya PubMed, Google scholar, dan open access science direct untuk mengetahui potensi studi yang memenuhi syarat. Kata kunci yang digunakan antara lain: 'Probiotic for pregnancy 'ATAU' 'Probiotic AND hypertension AND Prenancy' ATAU Probiotic AND Diabetus mellitus" ATAU 'Probiotic AND Pregnancy AND Review'. Penelusuran ini dilakukan mulai dari Februari hingga Maret 2020, kriteria artikel yang masuk dalam review kali ini adalah: Randomized controlled trial, studi retrospektif, observasional, studi kasus, review, systematic review, dan meta analisis.

\section{HASIL DAN PEMBAHASAN}

\section{Probiotik untuk bakterial vaginosis pada kehamilan}

Bakteri vaginosis (BV) adalah suatu kondisi yang ditandai dengan penurunan jumlah microbiota Lactobacillus spp. dan diikuti oleh peningkatan jumlah bakteri lain seperti Gardnerella vaginalis, Atopobium vaginae, Prevotella spp., Mobilucus spp, dan Mycoplasma hominis (Krauss-Silva et al., 2011; Darmayanti et al., 2017). Komplikasi BV pada kehamilan termasuk, ketuban pecah dini, postpartal endometritis, meningkatkan kegagalan dalam perkembangan kehamilan, dan kelahiran prematur (Vujic et al., 2013; Tri Darmayanti et al, 2019).

Probiotik melawan bakteri vaginosis melalui berbagai mekanisme, persaingan dengan patogen, stabilisasi lapisan mucin dan pencegahan pertumbuhan bakteri patogen dengan memproduksi zat antibakteri antara lain reutericyclin, asam organik, bakteriosin, reuterin dan hidrogen peroksida. Hidrogen peroksida (H2O2) sebagai hasil afinitas tinggi dengan oksigen dibandingkan dengan spesies lain. Efek $\mathrm{H} 2 \mathrm{O} 2$ pada bakteri patogen bergantung pada kemampuan pengoksidasi dinding sel bakteri. $\mathrm{H} 2 \mathrm{O} 2$ bekerja bersamaan dengan asam organik lainnya untuk mengatasi bakteri patogen seperti: Listeria monocytogenes, Bacillus cereus, Bacillus subtilis, Yersinia enterocolitica, Escherichia coli, Pseudomonas aeruginosa, Salmonella typhimurium, Gardnerela vaginalis dan Klebsiella pneumoniae(Hou et al., 2015; Jandhyala et al., 2015; Darmayanti et al., 2017).

\section{Probiotik dan Hipertensi pada kehamilan}

Mikrobiota usus berpotensi mempengaruhi tekanan darah melalui berbagai mekanisme. Bakteri jenis Streptococcus, Escherichia, Lactobacillus, dan Bifidobacterium genera dapat mensintesis neurotransmiter dalam sistem saraf otonom (Lyte, 2011). Perubahan pada prevalensi bakteri ini dapat mengubah tonus pembuluh darah dan berkontribusi terhadap perkembangan hipertensi. 
Mikrobiota usus memengaruhi respon inflamasi tubuh manusia, mengubah fungsi endotel, yang dapat berdampak pada penurunan tekanan darah (Aidy, Dinan and Cryan, 2014).

Selain itu, rantai pendek produksi asam lemak / Short Chain Fatty Acid (SCFA) oleh mikrobiota usus dikaitkan peran Bifidobacteria sebagai bakteri penghasil SCFA. Perawatan dengan antibiotik minocycline meningkatkan jumlah bakteri penghasil SCFA sambil mengurangi rata-rata tekanan darah arteri. Suplementasi dengan probiotik dilaporkan mengurangi tekanan darah, menunjukkan pentingnya mikrobiota usus dalam pengaturan tekanan darah selama kehamilan (Yang et al., 2015).

Dengan terkontrolnya tekanan darah pada kehamilan, maka kemungkinan penyakit penyerta lain dapat diatasi. Tekanan darah sangat penting dalam masa kehamilan, karena tekanan darah yang tinggi dan tidak terkontrol merupakan awal mula dari komplikasi lain seperti pre eklampsia dan eklampsia.

\section{Probiotik dan Diabetus Mellitus pada masa kehamilan}

Wanita yang kelebihan berat badan atau obesitas selama kehamilan, yang ditandai dengan Indeks Massa Tubuh (BMI) ibu yang tinggi, memiliki peningkatan risiko diabetes mellitus gestasional (GDM) . Obesitas ibu dapat mempengaruhi pertumbuhan janin pada tahap awal kehidupan. GDM ibu meningkatkan risiko adipositas yang berlebihan pada janin, makrosomia (kelahiran berat lebih dari 4000 g) dan hipoglikemia neonatal (Halkjaer et al., 2016).

Probiotik adalah mikroorganisme hidup yang bila diberikan dalam jumlah yang memadai, dapat memberi manfaat kesehatan pada tubuh. Probiotik terdiri dari individu atau beberapa spesies bakteri hidup (seperti lactobacilli dan bifidobacteria) yang selama asupan dapat mengubah mikrobiota usus. Penelitian terbaru menunjukkan bahwa mikrobiota usus dapat memainkan peran penting dalam pengembangan obesitas, peradangan terkait obesitas dan resistensi insulin. Studi intervensi dengan kapsul yang mengandung Lactobacillus rhamnosus GG dan Bifidobacterium lactis BB12 pada 256 wanita hamil dengan berat normal dan dilaporkan mengalami penurunan risiko GDM dari 34 hingga $13 \%(P=0,003)$ dengan kombinasi suplementasi diet / probiotik . penelitia lain terkait konsumsi $200 \mathrm{~g}$ yoghurt konvensional atau probiotik per hari mengandung dua strain lactobacilli (L. Acidophilus LA5) dan bifidobacteria (Bifidobacterium animalis BB12) selama 9 minggu. Menemukan perbedaan signifikan pada kadar insulin serum: $+1.2 \pm 1.2$ versus $+5.0 \pm 1.1 \mu \mathrm{IU} / \mathrm{ml}(\mathrm{P}=0,02)$, dan kesimpulannya adalah konsumsi yoghurt probiotik mempertahankan kadar insulin dalam serum dan mungkin membantu mencegah pengembangan resistensi insulin selama kehamilan (Luoto et al., 2010; Halkjaer et al., 2016).

\section{SIMPULAN}

Probiotik adalah mikroorganisme hidup yang bila diberikan dalam jumlah yang memadai, dapat memberi manfaat kesehatan pada tubuh. Penggunaan probiotik dapat mempengaruhi mikrobiota usus dan berpengaruh positif pada kehamilan. Bakteri jenis Lactobacillus dan Bifidobacterium dapat mengobati dan mencegah bakterial vainosis dengan memproduksi zat antibakteri antara lain reutericyclin, 
asam organik, bakteriosin, reuterin dan hidrogen peroksida. Hidrogen peroksida (H2O2).

Bakteri jenis Streptococcus, Escherichia, Lactobacillus, dan Bifidobacterium dapat mensintesis neurotransmiter dalam sistem saraf otonom, mengubah tonus pembuluh darah, mengubah fungsi endotel, dan memproduksi asam lemak / Short Chain Fatty Acid (SCFA) untuk menurunkan tekanan darah. Selain itu Lactobacillus rhamnosus GG dan Bifidobacterium lactis BB12 dilaporkan dapat menurunkan kadar insulin dan risiko GDM.

\section{SARAN}

Probiotik merupakan mikroba normal yang ada di dalam tubuh, sehingga penambahan dan penggunaannya dalam terapi dapat dipertimbangkan. Belum dilaporkan adanya efek samping berarti dari penggunaan probiotik dalam jangka panjang ataupun pendek, sehingga alternatif terapi probiotik sangat diperhitungkan untuk diberikan pada ibu hamil.

\section{DAFTAR PUSTAKA}

Aidy, S. El, Dinan, T. G. and Cryan, J. F. (2014) 'Immune modulation of the brain-gut-microbe axis', Frontiers in Microbiology. doi: 10.3389/fmicb.2014.00146.

Cani, P. D. and Delzenne, N. M. (2007) 'Gut microflora as a target for energy and metabolic homeostasis', Current Opinion in Clinical Nutrition and Metabolic Care doi: 10.1097/MCO.0b013e3282efdebb.

Darmayanti, A.T, Murti, B, Susilawati T.N. (2017) 'The Effectiveness of Adding Probiotic on Antimicrobial for Bacterial Vaginosis: A Systematic Review', Indonesian Journal of Medicine, 02(03), pp. 161-168. doi: 10.26911/theijmed.2017.02.03.03

Gomez-Arango, L. F. et al. (2016) 'Increased Systolic and Diastolic Blood Pressure is Associated with Altered Gut Microbiota Composition and Butyrate Production in Early Pregnancy', Hypertension, 68(4), pp. 974-981. doi: 10.1161/HYPERTENSIONAHA.116.07910.

Halkjaer, S. I. et al. (2016) 'Effects of probiotics (Vivomixx®) in obese pregnant women and their newborn: Study protocol for a randomized controlled trial', Trials. Trials, 17(1), pp. 1-9. doi: 10.1186/s13063-016-1617-5.

Hou, C. et al. (2015) 'Study and use of the probiotic Lactobacillus reuteri in pigs: a review', Journal of Animal Science and Biotechnology, 6(1), p. 14. doi: 10.1186/s40104-015-0014-3.

Jandhyala, S. M. et al. (2015) 'Role of the normal gut microbiota', World Journal of Gastroenterology, 21(29), pp. 8836-8847. doi: 10.3748/wjg.v21.i29.8787.

Krauss-Silva, L. et al. (2011) 'A randomised controlled trial of probiotics for the prevention of spontaneous preterm delivery associated with bacterial vaginosis: preliminary results', Trials. BioMed Central Ltd, 12(1), p. 239. 
doi: $10.1186 / 1745-6215-12-239$.

Lindsay, K. L. et al. (2013) 'Probiotics in pregnancy and maternal outcomes: A systematic review', Journal of Maternal-Fetal and Neonatal Medicine, 26(8), pp. 772-778. doi: 10.3109/14767058.2012.755166.

Luoto, R. et al. (2010) 'Impact of maternal probiotic-supplemented dietary counselling on pregnancy outcome and prenatal and postnatal growth: A double-blind, placebo-controlled study', British Journal of Nutrition. doi: 10.1017/S0007114509993898.

Lyte, M. (2011) 'Probiotics function mechanistically as delivery vehicles for neuroactive compounds: Microbial endocrinology in the design and use of probiotics', BioEssays. doi: 10.1002/bies.201100024.

Pelzer, E. et al. (2017) 'Review: Maternal health and the placental microbiome', Placenta. Elsevier Ltd, 54, pp. 30-37. doi: 10.1016/j.placenta.2016.12.003.

Tilg, H. and Kaser, A. (2011) 'Gut microbiome, obesity, and metabolic dysfunction', Journal of Clinical Investigation. doi: 10.1172/JCI58109.

Tri Darmayanti, A., Nugraha Susilawati, T. and Murti, B. (2019) 'Giving Probiotic for a Better Therapy of Bacterial Vaginosis', KnE Life Sciences, 4(12), p. 239. doi: 10.18502/kls.v4i12.4179.

Vujic, G. et al. (2013) 'Efficacy of orally applied probiotic capsules for bacterial vaginosis and other vaginal infections: A double-blind, randomized, placebo-controlled study', European Journal of Obstetrics Gynecology and Reproductive Biology. Elsevier Ireland Ltd, 168(1), pp. 75-79. doi: 10.1016/j.ejogrb.2012.12.031.

Yang, T. et al. (2015) 'Gut Dysbiosis is Linked to Hypertension', Hypertension. doi: 10.1161/HYPERTENSIONAHA.115.05315. 